\title{
Rapid human melanoma cell death induced by sanguinarine through oxidative stress
}

Ana Burgeiro ${ }^{1,2}$, Ana C. Bento ${ }^{1}$, Consuelo Gajate ${ }^{1}$, Paulo J. Oliveira ${ }^{2}$, and Faustino Mollinedo ${ }^{1}$

\footnotetext{
${ }^{1}$ Instituto de Biología Molecular y Celular del Cáncer, Centro de Investigación del Cáncer, Consejo Superior de Investigaciones Científicas (CSIC)-Universidad de Salamanca, Campus Miguel de Unamuno, E-37007 Salamanca, Spain.

${ }^{2}$ Center for Neurosciences and Cell Biology, Department of Life Sciences, University of Coimbra, 3004-517 Coimbra, Portugal
}

Short title: ROS involvement in sanguinarine-induced melanoma cell death

Keywords: Sanguinarine; human melanoma cells; reactive oxygen species; mitochondria; endoplasmic reticulum; caspase activation.

Corrresponding author: Faustino Mollinedo, Instituto de Biología Molecular y Celular del Cáncer, Centro de Investigación del Cáncer, Consejo Superior de Investigaciones Científicas (C.S.I.C.) - Universidad de Salamanca, Campus Miguel de Unamuno, Salamanca, E-37007 Salamanca, Spain; Tel.: (+34) 923 294806; Fax: (+34) 923 294795; E-mail: fmollin@usal.es 


\begin{abstract}
Sanguinarine is a natural isoquinoline alkaloid derived from the root of Sanguinaria canadensis and from other poppy fumaria species, and is known to have a broad spectrum of pharmacological properties. Here we have found that sanguinarine, at low micromolar concentrations, showed a remarkably rapid killing activity against human melanoma cells. Time-lapse videomicroscopy showed rapid morphological changes compatible with an apoptotic cell death, which was further supported by biochemical markers, including caspase activation, poly(ADP-ribose) polymerase (PARP) cleavage and DNA breakdown. Pancaspase inhibition blocked sanguinarine-induced cell death. Sanguinarine treatment also induced an increase in intracellular calcium concentration, which was inhibited by dantrolene, and cleavage of BAP-31, thus suggesting a putative role for $\mathrm{Ca}^{2+}$ release from endoplasmic reticulum and a cross-talk between endoplasmic reticulum and mitochondria in the antimelanoma action of sanguinarine. Sanguinarine disrupted the mitochondrial transmembrane potential $\left(\Delta \Psi_{\mathrm{m}}\right)$, released cytochrome $c$ and Smac/DIABLO from mitochondria to cytosol, and increased the generation of reactive oxygen species (ROS). Overexpression of Bcl- $\mathrm{X}_{\mathrm{L}}$ by gene transfer did not prevent sanguinarine-mediated cell death, ROS generation or release of mitochondrial apoptogenic proteins. However, preincubation with $N$-acetyl- $L$-cysteine (NAC) prevented sanguinarine-induced oxidative stress, PARP cleavage, release of apoptogenic mitochondrial proteins, and cell death. Pretreatment with glutathione (GSH) also inhibited the anti-melanoma activity of sanguinarine. Thus, pretreatment with the thiol antioxidants NAC and GSH abrogated the killing activity of sanguinarine. Taking together, our data indicate that sanguinarine is a very rapid inducer of human melanoma caspase-dependent cell death that is mediated by ROS generation.
\end{abstract}




\section{Introduction}

Sanguinarine (13-methyl[1,3]benzodioxolo[5,6-c]-1,3-dioxolo[4,5-i]phenanthridinium) is a natural isoquinoline alkaloid (Malikova et al., 2006) that can be found in plants of the Papaveraceae family, such as Sanguinaria canadensis. Sanguinarine has a broad spectrum of pharmacological activities, including antitumor (Faddeeva and Beliaeva, 1997), anti-bacterial (Mitscher et al., 1978), and anti-inflammatory (Lenfeld et al., 1981) actions. Sanguinarine has been reported to induce cell cycle arrest and apoptosis in distinct cancer cells (Adhami et al., 2004; Ahmad et al., 2000; Ahsan et al., 2007; Ding et al., 2002; Holy et al., 2006; KemenyBeke et al., 2006; Serafim et al., 2008; Weerasinghe et al., 2001).

Melanoma remains one of the most deadly skin cancers and its incidence has been steadily rising throughout the past decades (Cho and Chiang, 2010). Chemotherapy has had little impact on the survival of patients with metastatic melanoma (Hersey et al., 2009). So far, there is no efficient therapy against melanoma, hence the need of searching for new effective agents. Some previous reports have shown that sanguinarine was effective in treating melanoma in xenograft assays (De Stefano et al., 2009), and acted as a DNA damaging agent and partially affected mitochondrial-mediated processes in mouse melanoma K1735-M2 cell line (Serafim et al., 2008).

Mitochondria play a role in the chemotherapeutic action of a number of molecules that leads to cancer cell death. Mitochondrial damage, which involves permeabilization of the outer mitochondrial membrane, activates a series of events leading to cell death (Caroppi et al., 2009). The activation of the intrinsic apoptotic pathway involves release of cytochrome $c$ and other proapoptotic factors from the mitochondrial intermembrane space. In the cytosol, cytochrome $c$ binds to the apoptosis protease-activation factor (APAF-1) and forms a complex known as apoptosome, which then recruits and activates procaspase-9, thus triggering a cascade of events leading to apoptosis (Acehan et al., 2002). One of the consequences of mitochondrial dysfunction is excessive reactive oxygen species (ROS) production. Oxygen is initially converted to superoxide anion by electrons that can leak from both complexes I and III in the electron transport system present in mitochondria (Ishii, 2007). Oxidative stress results in damage to the cellular components, including mitochondrial structures, and eventually leads to apoptosis (Ishii, 2007). However, despite mitochondria constitute a major origin of ROS, additional sources have been reported (Vaquero et al., 2004).

Here, we have analyzed the action of sanguinarine on human melanoma cells as well as the underlying mechanisms, with special relevance to the putative role of mitochondria. 
The results reported here provide novel insights into the sanguinarine-mediated antimelanoma activity.

\section{Materials and methods}

\subsection{Reagents}

Sanguinarine chloride was from Alexis Biochemicals (Lausen, Switzerland) and prepared in dimethyl sulfoxide (DMSO). Total volume of vehicle (DMSO) in all experiments was lower than $0.2 \%$, and it rendered negligible effects (data not shown). Pan-caspase inhibitor z-VADfmk was from Alexis Biochemicals (Lausen). Trypan blue, propidium iodide, RNase A, $\mathrm{N}$ acetyl- $L$-cysteine (NAC), dantrolene, glutathione (GSH), dihydroethidine (DHE), and BSA were from Sigma (St. Louis, MO). 30\% Acrylamide/Bisacrylamide, ammonium persulfate, and $N, N, N^{\prime}, N^{\prime}$-tetramethylethylenediamine were from Bio-Rad (Hercules, CA). Hybond enhanced chemiluminescence (ECL) nitrocellulose membranes, and ECL Western blotting detection reagents were from GE Healthcare (Princeton, NJ). Fluo-4 AM, Hoechst 33342, 3,3'-dihexyloxacarbocyanine iodide $\left[\operatorname{DiOC}_{6}(3)\right]$, and tetramethyl rhodamine methyl ester (TMRM) were from Molecular Probes (Leiden, The Netherlands). Lipofectamine 2000 reagent was from Invitrogen (Eugene, OR). RPMI-1640, FBS, antibiotics, L-glutamine, NaP, NEAA, $0.25 \%$ Trypsin-EDTA were purchased from Gibco (Carlsbad, CA).

\subsection{Cell culture}

The human melanoma cell lines SK-MEL-2, SK-MEL-5, SK-MEL-28 and MALME-3M were obtained from the American Type Culture Collection (ATCC, Manassas, VA). All these cells were derived from malignant melanoma. However, SK-MEL-2, SK-MEL-5 and MALME-3M cells were also metastatic cell lines, their metastatic sites being the skin of thigh, axillary node and lung, respectively. Cell lines were grown in RPMI-1640 supplemented with 15\% heatinactivated FBS, $2 \mathrm{mM}$ L-glutamine, 100 units $/ \mathrm{ml}$ penicillin, $100 \mu \mathrm{g} / \mathrm{ml}$ streptomycin at $37^{\circ} \mathrm{C}$ in $5 \% \mathrm{CO}_{2}$ humidified air. For SK-MEL-2, SK-MEL-5 and SK-MEL-28 cell lines, the medium was also supplemented with $1 \mathrm{mM}$ of sodium pyruvate $(\mathrm{NaP})$ and $1 \%$ non-essential amino acids (NEAA). Cells were periodically tested for Mycoplasma infection and found to be negative.

\subsection{Cell viability and cell death analysis}

Sanguinarine was incubated at various concentrations with human melanoma cell lines for the indicated times, and then cell viability was determined by using Trypan Blue dye reagent 
(Sigma). Non-viable cells stained blue due to Trypan Blue uptake, while viable cells excluded Trypan Blue and showed normal refringent cytoplasm. Cell samples were counted under the light microscope, and the percentage of non-viable cells was determined. Apoptotic cell death was analyzed in situ by the terminal deoxynucleotidyl transferase-mediated dUTP nick-end labeling (TUNEL) technique using the Fluorescein Apoptosis Detection System Kit (Promega, Fitchburg, WI), according to the manufacturer's instructions, labeling the 3'-OH ends generated by DNA fragmentation through incorporation of fluorescein-12-dUTP (Cabaner et al., 1999; Gavrieli et al., 1992). Fluorescent cells were visualized and scored with a Zeiss LSM 310 laser scan confocal microscope.

\subsection{Western blotting in total cell extracts}

Cells at approximately $70 \%$ of confluence (about $1.0 \times 10^{6}$ ) were lysed with $60 \mu 1$ of $25 \mathrm{mM}$ Hepes (pH 7.7), $0.3 \mathrm{mM} \mathrm{NaCl}, 1.5 \mathrm{mM} \mathrm{MgCl}_{2}, 0.2 \mathrm{mM}$ EDTA, 0.1\% Triton X-100, $20 \mathrm{mM}$ $\beta$-glycerophosphate and $0.1 \mathrm{mM}$ sodium orthovanadate supplemented with protease inhibitors (1 $\mathrm{mM}$ phenylmethylsulfonyl fluoride, $20 \mu \mathrm{g} / \mathrm{ml}$ aprotinin, $20 \mu \mathrm{g} / \mathrm{ml}$ leupeptin). Fifty micrograms of protein extract were run on SDS-polyacrylamide gels, transferred to hybond ECL nitrocellulose membranes, blocked with $5 \%(\mathrm{w} / \mathrm{v})$ defatted milk powder in TBST (50 $\mathrm{mM}$ Tris-HCl, $\mathrm{pH} 8.0,150 \mathrm{mM} \mathrm{NaCl}, 0.1 \%$ Tween 20) for $60 \mathrm{~min}$ at room temperature, and incubated for $1 \mathrm{~h}$ at room temperature, or overnight at $4^{\circ} \mathrm{C}$, with the following specific antibodies: anti-17 and $19 \mathrm{kDa}$ active caspase-3 rabbit polyclonal antibody (1:750 dilution, Cell Signaling Technology, Beverly, MA); N-15 anti-50 kDa caspase-4 goat polyclonal antibody, that also detects the active cleaved p20 subunit (1:250 dilution, Santa Cruz Biotechnology, Santa Cruz, CA); anti-35 kDa caspase-7 mouse monoclonal antibody, that also recognizes the cleaved p11, p20 and p32 subunits (1:750 dilution, BD Biosciences, San Jose, CA); $1 \mathrm{C} 12$ anti-57 kDa caspase- 8 mouse monoclonal antibody, that also detects the cleaved p43 and p18 subunits (1:500 dilution, Cell Signaling Technology); anti-47 kDa caspase-9 rabbit polyclonal antibody, that also recognizes the cleaved p10, p17 and p38 subunits (1:250 dilution, Calbiochem, Gibbstown, NJ); C2.10 anti-116 kDa poly(ADP-ribose) polymerase (PARP) mouse monoclonal antibody, that also detects the $85 \mathrm{kDa}$ cleavage product (1:750 dilution, BD Biosciences); anti-58 kDa caspase-10 rabbit polyclonal antibody, that also recognizes the p17 and p23 subunits (1:50 dilution, Calbiochem); C-15 anti-31 kDa BAP-31 goat polyclonal antibody, that also detects the $20 \mathrm{kDa}$ cleavage product (1:500 dilution, Santa Cruz Biotechnology); AC-15 anti-42 kDa $\beta$-actin mouse monoclonal antibody (1:5,000 dilution, Sigma). Secondary antibodies were anti-mouse biotinylated (GE 
Healthcare, Princeton, NJ); anti-rabbit biotinylated (GE Healthcare) and anti-goat horseradish peroxidase (Santa Cruz Biotechnology). When secondary biotinylated antibodies were used, membranes were subsequently incubated with streptavidin-horseradish peroxidase conjugate (GE Healthcare). Signals were detected using an ECL kit (GE Healthcare).

\subsection{Analysis of mitochondrial protein release}

Release of apoptogenic proteins from mitochondria to cytosol was analyzed from $3 \times 10^{6}$ cells by Western blot as previously described (Gajate et al., 2003), using the following specific antibodies: anti-15 kDa cytochrome $c$ mouse monoclonal antibody (1:500 dilution, BD Biosciences); anti-22 kDa Smac/DIABLO mouse monoclonal antibody (1:500 dilution, BD Biosciences); AC-15 anti-42 kDa $\beta$-actin monoclonal antibody (1:5,000, Sigma). Blots were then incubated with biotinylated anti-mouse inmunoglobulin antibodies (GE Healthcare), followed by incubation with streptavidin-horseradish peroxidase conjugate (GE Healthcare). Signals were developed using an ECL kit (GE Healthcare).

\subsection{Cytofluorimetric analysis of intracellular calcium and mitochondrial transmembrane potential}

To evaluate changes in intracellular calcium concentration, cells were incubated with or without $3 \mu \mathrm{M}$ Sanguinarine for $2 \mathrm{~h}$, and $30 \mathrm{~min}$ before the end of the treatment, $2 \mu \mathrm{M}$ Fluo- 4 AM (green fluorescence) was used to measure intracellular calcium. Cells were then washed with PBS, harvested and analyzed on a flow cytometer FACSCalibur (Becton Dickinson, Franklin Lakes, NJ). To evaluate changes in mitochondrial transmembrane potential $\left(\Delta \Psi_{\mathrm{m}}\right)$, cells were incubated with or without $3 \mu \mathrm{M}$ Sanguinarine for $2 \mathrm{~h}$, and $30 \mathrm{~min}$ before the end of the treatment $100 \mathrm{nM}$ tetramethyl rhodamine methyl ester (TMRM) (red fluorescence) (Molecular Probes) was added to measure mitochondrial membrane potential $\left(\Delta \Psi_{\mathrm{m}}\right)$. Cells were then washed with PBS, harvested and analyzed on a flow cytometer FACSCalibur (Becton Dickinson). In addition, mitochondrial transmembrane potential $\left(\Delta \Psi_{\mathrm{m}}\right)$ was also

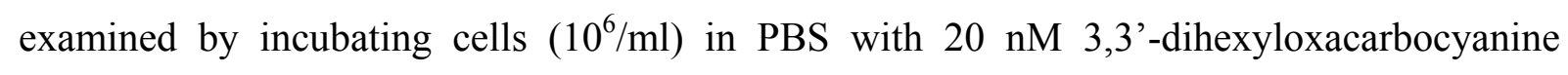
iodide $\left[\mathrm{DiOC}_{6}(3)\right]$ (green fluorescence) (Molecular Probes) for $20 \mathrm{~min}$ at $37^{\circ} \mathrm{C}$, followed by analysis on a flow cytometer FACSCalibur (Becton Dickinson).

\subsection{Measurement of reactive oxygen species (ROS) generation by flow cytometry}


To evaluate the generation of ROS, cells were incubated in PBS with $2 \mu \mathrm{M}$ dihydroethidine (DHE) (red fluorescence after oxidation) for $40 \mathrm{~min}$ at $37^{\circ} \mathrm{C}$, followed by analysis on a FACScalibur flow cytometer as previously decribed (Gajate et al., 2000).

\subsection{Confocal microscopy}

SK-MEL-2 cells in glass-bottom dishes were incubated with $3 \mu \mathrm{M}$ sanguinarine for $2 \mathrm{~h}$. Then, cells were double labeled with Fluo-4 AM $(2 \mu \mathrm{M})$ and Hoechst $33342(2 \mu \mathrm{g} / \mathrm{ml})$, added to the cell culture $1 \mathrm{~h}$ and $30 \mathrm{~min}$, respectively, or with DHE $(2 \mu \mathrm{M})$ and Hoechst $33342(2 \mu \mathrm{g} / \mathrm{ml})$, added to the cell culture 40 and $30 \mathrm{~min}$, respectively, before the end of drug treatment. Then, cells were analyzed by confocal microscopy using a Leica laser scanning confocal microscope (Bannockburn, IL). Fluo-4 AM signal was acquired using an air-cooled argon laser. DHE signal was acquired using a green He-Ne laser. Hoechst 33342 signal was obtained by using a violet diode laser. The antifading reagent SlowFade ${ }^{\circledR}$ Gold (Invitrogen, Eugene, OR) was used to preserve fluorescence signal intensity.

\subsection{Overexpression of bcl- $x_{L}$ by stable transfection}

SK-MEL-2 cells were transfected with $8 \mu \mathrm{g}$ of pSFFV-Neo expression vector containing the human $b c l-x_{L}$ open reading frame, driven by the long terminal repeat of the splenic focusforming virus (pSFFV-Bcl- $\mathrm{X}_{\mathrm{L}}$ ) (Mollinedo et al., 1997), by using Lipofectamine reagent (Invitrogen, Eurogene, OR) and following the manufacturer's instructions. As a control, transfection was performed with empty pSFFV-Neo plasmid. Transfectants were selected by

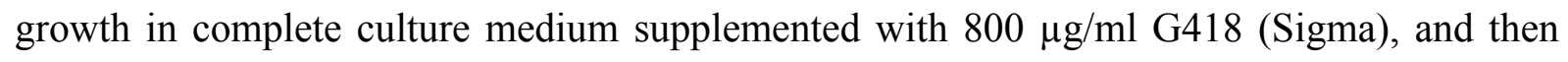
grown in the presence of $250 \mu \mathrm{g} / \mathrm{ml} \mathrm{G} 418$. Stable transfectants were achieved after about 30 days. The different clones were isolated and monitored for $\mathrm{Bcl}-\mathrm{X}_{\mathrm{L}}$ expression by Western blot, using the anti-17 and $-26 \mathrm{kDa}$ Bcl-X rabbit polyclonal antibody (1:250 dilution, BD Biosciences).

\subsection{Statistical analysis}

Data are expressed as means $\pm \mathrm{SD}$ of the number of experiments indicated in the figure legends. Multiple comparisons were performed using one-way analysis of variance followed by a Bonferroni post hoc test. Single comparisons between two experimental groups were made by using Student's $t$-test. Significance was accepted with $p$ value $<0.05$.

\section{Results}




\subsection{Sanguinarine induces a rapid killing of human melanoma cells}

We found that sanguinarine induced a rapid killing of SK-MEL-2 melanoma cancer cells when incubated at low micromolar concentration for only $2 \mathrm{~h}$ incubation, as assessed by Trypan blue staining (Fig. 1A). A potent melanoma cell-killing activity was evident at $3 \mu \mathrm{M}$ sanguinarine when incubated for either 2 or $24 \mathrm{~h}$ (Fig. 1A). The tumor killing activity of sanguinarine was increased with drug concentration and incubation time, but sanguinarine induced a remarkable and strong antitumor activity at early incubation times (Fig. 1A). Furthermore, $3 \mu \mathrm{M}$ sanguinarine induced a decrease in cell viability following $2 \mathrm{~h}$ incubation in a number of human melanoma cell lines, including SK-MEL-2 (47.4 $\pm 8.0 \%$ cell death), SK-MEL-5 (21.2 $\pm 1.5 \%$ cell death), SK-MEL-28 (15.6 $\pm 1.5 \%$ cell death) and MALME$3 \mathrm{M}(28.1 \pm 1.7 \%$ cell death), as assessed by Trypan blue staining (Fig. 1B). Treatment of SKMEL-2 cells with $3 \mu \mathrm{M}$ sanguinarine induced an increase in non-viable cells at very early incubation times in a time-dependent manner (Fig. 1C), which was also confirmed by morphological changes (Fig. 1D). Time-lapse videomicroscopy of untreated (Supplementary Video 1) and $3 \mu \mathrm{M}$ sanguinarine-treated (Supplementary Video 2) SK-MEL-2 melanoma cells showed a remarkably rapid killing of melanoma cells by sanguinarine, which displayed the typical morphological changes of apoptosis (cell shrinkage, rounding up, blebbing). The onset of this sanguinarine-induced killing of melanoma cells was achieved after only $25 \mathrm{~min}$ of drug incubation (Supplementary Video 2). The induction of sanguinarine-induced cell death by an apoptosis-like process in melanoma cells was further supported by TUNEL assay (data not shown).

\subsection{Involvement of caspase activation in sanguinarine-induced melanoma cell killing}

Because SK-MEL-2 cells were the most sensitive melanoma cells to sanguinarine treatment (Fig. 1B), this cell line was used in the following experiments to analyze the underlying mechanism involved in sanguinarine-mediated melanoma cell killing. Sanguinarine treatment of SK-MEL-2 cells induced a rapid activation of several caspases, including initiator caspases 8, 10, 9 and 4, as well as executioner caspases 3 and 7 (Fig. 2A). Cleavage of the caspase-3/7 substrate PARP, a nuclear enzyme involved in DNA repair and programmed cell death, was also rapidly detected (Fig. 2A). Pre-incubation of melanoma cells with the pan-caspase inhibitor $z-V A D-f m k$ prevented cell killing induced by $3 \mu \mathrm{M}$ sanguinarine after treatment for either 2 or $24 \mathrm{~h}$ incubation (Fig. 2B). These results suggest that caspase activation is required for sanguinarine-induced melanoma cell killing, and that several caspases are triggered by sanguinarine in a similar time frame. 


\subsection{Sanguinarine increases intracellular calcium and induces BAP-31 cleavage in melanoma}

cells

We found that sanguinarine treatment caused an increase in intracellular calcium concentration in SK-MEL-2 cells, as detected by Fluo-4 AM and analyzed by both confocal microscopy (Fig. 3A) and flow cytometry (Fig. 3B). In addition, sanguinarine induced cleavage of BAP-31 (Fig. 3C), an endoplasmic reticulum membrane protein that is a caspase8 substrate (Ng et al., 1997). The p20-BAP31 cleavage product has been shown to direct proapoptotic signals between endoplasmic reticulum and mitochondria (Breckenridge et al., 2003). Interestingly, incubation of SK-MEL-2 melanoma cells with dantrolene significantly inhibited the killing activity of sanguinarine (Fig. 3D). Dantrolene prevents excessive $\mathrm{Ca}^{2+}$ release from the endoplasmic reticulum by inhibiting ryanodine receptors (Inan and Wei, 2010; Zhao et al., 2001). These data suggest that $\mathrm{Ca}^{2+}$ release endoplasmic reticulum might play a role in the action of sanguinarine on melanoma cells. Our data suggest that sanguinarine might induce some endoplasmic reticulum-mediated responses that could affect mitochondria.

3.4. Sanguinarine induces $R O S$ generation, $\Delta \Psi_{m}$ loss and release of mitochondrial apoptogenic proteins

Next, we analyzed the effect of sanguinarine on mitochondrial-mediated cell death. Sanguinarine ( $3 \mu \mathrm{M}, 2 \mathrm{~h}$ incubation) induced a potent and rapid generation of ROS in SKMEL-2 cells, as assessed by dihydroethidine (DHE) fluorescence using flow cytometry (Fig. 4A), and confocal microscopy (Fig. 4B). Sanguinarine also promoted $\Delta \Psi_{\mathrm{m}}$ loss in SK-MEL-2 melanoma cells in a concentration-dependent manner, as assessed by measurements of $\mathrm{DiOC}_{6}(3)$ fluorescence (green fluorescence), a cationic probe that accumulates into mitochondria as a function of its potential (Fig. 4C). The increase in the percentage of melanoma cells with low $\Delta \Psi_{\mathrm{m}}$ following sanguinarine treatment paralleled its cell-killing activity (cf. Figs. 1A and 4C). Sanguinarine also promoted a dramatic $\Delta \Psi_{\mathrm{m}}$ loss in melanoma cells, as assessed by TMRM fluorescence (red fluorescence) to measure $\Delta \Psi_{\mathrm{m}}$ (Fig. 4D), and the release of mitochondrial cytochrome $c$ and Smac/DIABLO to the cytosol after only 30min treatment (Fig. 4E). However, cytochrome oxidase subunit II, used as a marker of mitochondrial membrane, remained in the mitochondrial extract and was not released to the cytosol (data not shown). No alterations in ATP/ADP ratio or energy charge were detected after $30 \mathrm{~min}-, 1 \mathrm{~h}$ - and $2 \mathrm{~h}$-drug treatment (data not shown). These results suggest that 
sanguinarine exerts a rapid effect on mitochondrial integrity, leading to depolarization and release of proapoptotic proteins.

\subsection{Sanguinarine-mediated cell death is not prevented by Bcl- $X_{L}$ overexpression}

Because Bcl- $X_{\mathrm{L}}$ preserves mitochondrial integrity, abrogating cytochrome $c$ release, $\Delta \Psi_{\mathrm{m}}$ loss and apoptosis (Gajate and Mollinedo, 2007; Gajate et al., 2000), we overexpressed Bcl- $\mathrm{X}_{\mathrm{L}}$ in SK-MEL-2 cells to examine the role of mitochondria in sanguinarine-induced cell death. SKMEL-2 cells were stably transfected with pSFFV-bcl- $x_{L}$ (SK-MEL-2-Bcl-X $\mathrm{X}_{\mathrm{L}}$ ), containing the human $b c l-x_{L}$ open reading frame, or with control pSFFV-Neo plasmid (SK-MEL-2-Neo). SK-MEL-2-Neo cells behaved as non-transfected SK-MEL-2 cells in all parameters studied. Western blot analysis showed a high expression of Bcl- $\mathrm{X}_{\mathrm{L}}$ in SK-MEL-2-Bcl- $\mathrm{X}_{\mathrm{L}}$ cells as compared to the low Bcl-X $\mathrm{L}_{\mathrm{L}}$ endogenous level of SK-MEL-2-Neo cells (Fig. 5A, inset). Interestingly, while Bcl- $\mathrm{X}_{\mathrm{L}}$ overexpression inhibited cell death induced by a number of proapoptotic agents, including edelfosine and berberine (data not shown), as previously reported (Burgeiro et al., 2011; Gajate and Mollinedo, 2007), it did not protect against cell death, PARP degradation, ROS generation or the release of mitochondrial cytochrome $c$ and Smac/DIABLO to cytosol induced by sanguinarine (Fig. 5, A-D). These data show that the action of sanguinarine on mitochondria is not inhibited by Bcl- $\mathrm{X}_{\mathrm{L}}$ overexpression.

\subsection{N-Acetyl-L-cysteine and glutathione (GSH) protect melanoma cells against sanguinarine- induced cell death}

Pretreatment of SK-MEL-2 cells with the antioxidant $N$-acetyl- $L$-cysteine (NAC) prevented sanguinarine-induced cell death (Fig. 6A) and PARP cleavage (Fig. 6B). NAC pretreatment also blocked oxidative stress (Fig. 6C), and release of mitochondrial cytochrome $c$ and Smac/DIABLO to the cytosol (Fig. 6D). Because NAC is known to induce intracellular glutathione (GSH) levels by acting as a precursor for the synthesis of GSH (Duyndam et al., 2001; Menon et al., 2005), we also examined the action of GSH on the cell killing activity of sanguinarine. As shown in Fig. 7, we found that GSH inhibited significantly the antimelanoma activity of sanguinarine when incubated for either 2 or $24 \mathrm{~h}$. Thus, pretreatment with the thiol antioxidants NAC and GSH abrogated the cell-killing activity of sanguinarine. These results suggest the involvement of ROS generation in the rapid action of sanguinarine on mitochondria and cell killing.

\section{Discussion}


Here, we report that sanguinarine induces an extremely rapid caspase- and ROS-dependent cell killing in human melanoma cells. Time-lapse videomicroscopy showed the rapid shrinkage, rounding up and blebbing of melanoma cells following sanguinarine treatment. These morphological changes, together with a positive TUNEL reaction, suggest the induction of sanguinarine-induced cell death by an apoptosis-like process in melanoma cells. The activation of different caspases upon sanguinarine addition suggests the triggering of distinct signaling pathways. The rapid activation of caspases-4 and -9 suggests the involvement of endoplasmic reticulum and mitochondria in the antitumor action of sanguinarine.

Adenoviral expression of the p20 cleavage fragment from the endoplasmic reticulum membrane protein BAP-31 has been reported to cause an early release of $\mathrm{Ca}^{2+}$ from the endoplasmic reticulum, concomitant $\mathrm{Ca}^{2+}$ uptake by mitochondria, and mitochondrial recruitment of Drp1, a dynamin-related protein that mediates scission of the outer mitochondrial membrane, resulting in fission of the mitochondrial network (Breckenridge et al., 2003). Generation of the p20-BAP-31 fragment was detected after $2 \mathrm{~h}$ sanguinarine incubation, coincident with caspase- 8 activation. Sanguinarine also caused an increase in cytosolic $\left[\mathrm{Ca}^{2+}\right]$. Elevation of cytosolic $\left[\mathrm{Ca}^{2+}\right]$ can result from $\mathrm{Ca}^{2+}$-influx from the extracellular space or from $\mathrm{Ca}^{2+}$-release from intracellular stores, especially from endoplasmic reticulum (Bergner and Huber, 2008). The inhibition of sanguinarine-induced cell killing by dantrolene, a ryanodine receptor inhibitor that prevents $\mathrm{Ca}^{2+}$ release from the endoplasmic reticulum (Inan and Wei, 2010; Zhao et al., 2001), further supports a role of endoplasmic reticulum in the anti-melanoma action of sanguinarine. The increase in cytoplasmic $\left[\mathrm{Ca}^{2+}\right]$ following sanguinarine treatment might originate, at least in part, from extracellular $\mathrm{Ca}^{2+}$, as sanguinarine-induced cardiac muscle contracture has been shown to be inhibited by chelation of extracellular $\mathrm{Ca}^{2+}$ or addition of the $\mathrm{Ca}^{2+}$ antagonist $\mathrm{La}^{3+}$ (Hu et al., 2005). In this regard, it is worthy to note that the process known as calcium-induced calcium release (CICR), by which calcium is able to activate calcium release from intracellular $\mathrm{Ca}^{2+}$ stores (e.g.: endoplasmic reticulum), is primarily mediated by the the ryanodine receptor and $\mathrm{Ca}^{2+}$ release from the endoplasmic reticulum (Islam et al., 1992; Verkhratsky and Shmigol, 1996). In addition, we have found that pretreatment of SK-MEL-2 cells with the extracellular calcium chelator EGTA partially reduces the killing activity of sanguinarine (data not shown).

Previous studies showed that sanguinarine treatment increased cytosolic levels of cytochrome $c$, and active forms of caspases-3, -7, -8 and -9, leading to PARP cleavage and apoptotic cell death in immortalized human HaCaT keratinocytes (Adhami et al., 2003). Our 
data show that sanguinarine compromised mitochondrial integrity, resulting in mitochondrial depolarization and release of apoptogenic proteins. However, overexpression of $\mathrm{Bcl}-\mathrm{X}_{\mathrm{L}}$, an antiapoptotic protein that mediates its effects through heterodimerization with the $\mathrm{BH} 3$ region of proapoptotic molecules, did not prevent sanguinarine-induced cell death, PARP cleavage, release of mitochondrial apoptogenic proteins, or oxidative stress response. It has been reported that sanguinarine, in addition to be effective in displacing bound $\mathrm{BH} 3$ peptides, binds at the $\mathrm{BH} 1$ region of $\mathrm{Bcl}-\mathrm{X}_{\mathrm{L}}$, thus sanguinarine might antagonize other pro-survival mechanisms in addition to the one that involves BH3 region binding (Zhang et al., 2006). In this regard, a number of reports indicate that sanguinarine downregulates Bcl-2, thus altering the Bcl-2/Bax ratio in different tumor cells (Han et al., 2008; Kim et al., 2008; Lee et al., 2012; Tsukamoto et al., 2011). Furthermore, recent evidence suggests that the antiproliferative activity of sanguinarine in malignant melanoma cells is independent of their p53 status (Hammerova et al., 2011).

Sanguinarine treatment has been reported to induce apoptosis in PC3 human prostatic adenocarcinoma cells through an early and severe glutathione (GSH)-depleting effect (Debiton et al., 2003). GSH is an endogenous antioxidant (Dodd et al., 2008) that acts as a redox buffer to preserve the reduced intracellular environment (Fraternale et al., 2006). Our present results show that sanguinarine induces a significant increase in oxidative stress in SKMEL-2 cells, and the thiol antioxidant NAC, which increases GSH level (Duyndam et al., 2001; Menon et al., 2005), prevents an increase in ROS level, the release of mitochondrial apoptogenic proteins to the cytosol, as well as cell death. In addition, we report here that GSH inhibits significantly the anti-melanoma activity of sanguinarine. Taken together, our data indicate that the oxidative stress triggered in melanoma cells by sanguinarine underlies the subsequent mitochondrial depolarization and release of mitochondrial apoptogenic proteins.

By using sanguinarine self-fluorescence, nuclear accumulation of this alkaloid in mouse melanoma K1735-M2 cells has been observed (Serafim et al., 2008). Mitochondrial dysfunction was associated with nuclear DNA damage, and p53 was translocated to mitochondria upon sanguinarine treatment of mouse melanoma cells (Serafim et al., 2008). However, sanguinarine has also been reported to cause oxidative DNA damage and rapid apoptosis, that is not mediated by p53-dependent DNA damage signaling (Matkar et al., $2008 \mathrm{a} ; \mathrm{b})$. Here, we have found that human melanoma cells undergo a very rapid cell death response, which involves oxidative stress, following sanguinarine treatment. Thus, the 
induction of a potent oxidative response seems to be critical for the anti-melanoma action of sanguinarine.

The results reported here indicate that ROS generation, which in turn leads to mitochondrial dysfunction, is critical in sanguinarine-induced cell death in human melanoma cells. The rapid antitumor action of sanguinarine suggests that this drug could have a potential pharmaceutical application for the treatment of hyperproliferative skin disorders, including melanoma.

\section{Conclusions}

The data reported here show that sanguinarine induces a rapid caspase-dependent cell death in human melanoma cells, partially involving endoplasmic reticulum- and mitochondriamediated responses. This cell death is dependent on the generation of reactive oxygen species, and is not prevented by $\mathrm{Bcl}-\mathrm{X}_{\mathrm{L}}$ overexpression. The fact that sanguinarine induces a very rapid cell death with apoptotic features in melanoma cells, together with the lack of inhibition by overexpressing $\mathrm{Bcl}-\mathrm{X}_{\mathrm{L}}$, highlight the potent anti-melanoma activity of this isoquinoline alkaloid and suggest its potential in the treatment of skin cancer.

\section{Acknowledgments}

This work was supported by grants from the Fundaçao para a Ciencia e Tecnologia (FCT) (Ministério da Ciência, Tecnologia e Ensino Superior of Portugal) (PTDC/QUIQUI/101409/2008) to P.J.O.; Ministerio de Economía y Competitividad of Spain (SAF200802251, SAF2011-30518), Red Temática de Investigación Cooperativa en Cáncer, Instituto de Salud Carlos III, cofunded by the Fondo Europeo de Desarrollo Regional of the European Union (RD06/0020/1037 and RD12/0036/0065) to F.M.; Fondo de Investigación Sanitaria and European Commission (PS09/01915) to C.G.; Junta de Castilla y León (CSI052A11-2, CSI221A12-2, GR15-Experimental Therapeutics and Translational Oncology Program, and Biomedicine Project 2010-2011) to F.M and C.G.

A.B. was recipient of a predoctoral fellowship from the Portuguese FCT (SFRH/BD/32943/2006). C.G. was supported by the Ramón y Cajal Program from the Spanish Ministerio de Ciencia e Innovación. 


\section{References}

Acehan, D., Jiang, X., Morgan, D.G., Heuser, J.E., Wang, X., Akey, C.W., 2002. Threedimensional structure of the apoptosome: implications for assembly, procaspase-9 binding, and activation. Mol Cell 9, 423-432.

Adhami, V.M., Aziz, M.H., Mukhtar, H., Ahmad, N., 2003. Activation of prodeath Bcl-2 family proteins and mitochondrial apoptosis pathway by sanguinarine in immortalized human HaCaT keratinocytes. Clin Cancer Res 9, 3176-3182.

Adhami, V.M., Aziz, M.H., Reagan-Shaw, S.R., Nihal, M., Mukhtar, H., Ahmad, N., 2004. Sanguinarine causes cell cycle blockade and apoptosis of human prostate carcinoma cells via modulation of cyclin kinase inhibitor-cyclin-cyclin-dependent kinase machinery. Mol Cancer Ther 3, 933-940.

Ahmad, N., Gupta, S., Husain, M.M., Heiskanen, K.M., Mukhtar, H., 2000. Differential antiproliferative and apoptotic response of sanguinarine for cancer cells versus normal cells. Clin Cancer Res 6, 1524-1528.

Ahsan, H., Reagan-Shaw, S., Breur, J., Ahmad, N., 2007. Sanguinarine induces apoptosis of human pancreatic carcinoma AsPC-1 and BxPC-3 cells via modulations in Bcl-2 family proteins. Cancer Lett 249, 198-208.

Bergner, A., Huber, R.M., 2008. Regulation of the endoplasmic reticulum $\mathrm{Ca}^{2+}$-store in cancer. Anticancer Agents Med Chem 8, 705-709.

Breckenridge, D.G., Stojanovic, M., Marcellus, R.C., Shore, G.C., 2003. Caspase cleavage product of BAP31 induces mitochondrial fission through endoplasmic reticulum calcium signals, enhancing cytochrome $c$ release to the cytosol. J Cell Biol 160, 11151127.

Burgeiro, A., Gajate, C., Dakir el, H., Villa-Pulgarin, J.A., Oliveira, P.J., Mollinedo, F., 2011. Involvement of mitochondrial and B-RAF/ERK signaling pathways in berberineinduced apoptosis in human melanoma cells. Anticancer Drugs 22, 507-518.

Cabaner, C., Gajate, C., Macho, A., Munoz, E., Modolell, M., Mollinedo, F., 1999. Induction of apoptosis in human mitogen-activated peripheral blood $\mathrm{T}$ - lymphocytes by the ether phospholipid ET-18- $\mathrm{OCH}_{3}$ : involvement of the Fas receptor/ligand system. $\mathrm{Br} \mathrm{J}$ Pharmacol 127, 813-825.

Caroppi, P., Sinibaldi, F., Fiorucci, L., Santucci, R., 2009. Apoptosis and human diseases: mitochondrion damage and lethal role of released cytochrome $\mathrm{C}$ as proapoptotic protein. Curr Med Chem 16, 4058-4065. 
Cho, Y.R., Chiang, M.P., 2010. Epidemiology, staging (new system), and prognosis of cutaneous melanoma. Clin Plast Surg 37, 47-53.

De Stefano, I., Raspaglio, G., Zannoni, G.F., Travaglia, D., Prisco, M.G., Mosca, M., Ferlini, C., Scambia, G., Gallo, D., 2009. Antiproliferative and antiangiogenic effects of the benzophenanthridine alkaloid sanguinarine in melanoma. Biochem Pharmacol 78, 1374-1381.

Debiton, E., Madelmont, J.C., Legault, J., Barthomeuf, C., 2003. Sanguinarine-induced apoptosis is associated with an early and severe cellular glutathione depletion. Cancer Chemother Pharmacol 51, 474-482.

Ding, Z., Tang, S.C., Weerasinghe, P., Yang, X., Pater, A., Liepins, A., 2002. The alkaloid sanguinarine is effective against multidrug resistance in human cervical cells via bimodal cell death. Biochem Pharmacol 63, 1415-1421.

Dodd, S., Dean, O., Copolov, D.L., Malhi, G.S., Berk, M., 2008. N-acetylcysteine for antioxidant therapy: pharmacology and clinical utility. Expert Opin Biol Ther 8, $1955-$ 1962.

Duyndam, M.C., Hulscher, T.M., Fontijn, D., Pinedo, H.M., Boven, E., 2001. Induction of vascular endothelial growth factor expression and hypoxia-inducible factor 1alpha protein by the oxidative stressor arsenite. J Biol Chem 276, 48066-48076.

Faddeeva, M.D., Beliaeva, T.N., 1997. Sanguinarine and ellipticine cytotoxic alkaloids isolated from well-known antitumor plants. Intracellular targets of their action. Tsitologiia 39, 181-208.

Fraternale, A., Paoletti, M.F., Casabianca, A., Oiry, J., Clayette, P., Vogel, J.U., Cinatl, J., Jr., Palamara, A.T., Sgarbanti, R., Garaci, E., Millo, E., Benatti, U., Magnani, M., 2006. Antiviral and immunomodulatory properties of new pro-glutathione (GSH) molecules. Curr Med Chem 13, 1749-1755.

Gajate, C., An, F., Mollinedo, F., 2003. Rapid and selective apoptosis in human leukemic cells induced by Aplidine through a Fas/CD95- and mitochondrial-mediated mechanism. Clin Cancer Res 9, 1535-1545.

Gajate, C., Mollinedo, F., 2007. Edelfosine and perifosine induce selective apoptosis in multiple myeloma by recruitment of death receptors and downstream signaling molecules into lipid rafts. Blood 109, 711-719.

Gajate, C., Santos-Beneit, A.M., Macho, A., Lazaro, M., Hernandez-De Rojas, A., Modolell, M., Munoz, E., Mollinedo, F., 2000. Involvement of mitochondria and caspase-3 in ET-18-OCH 3 -induced apoptosis of human leukemic cells. Int J Cancer 86, 208-218. 
Gavrieli, Y., Sherman, Y., Ben-Sasson, S.A., 1992. Identification of programmed cell death in situ via specific labeling of nuclear DNA fragmentation. J Cell Biol 119, 493-501.

Hammerova, J., Uldrijan, S., Taborska, E., Slaninova, I., 2011. Benzo[c]phenanthridine alkaloids exhibit strong anti-proliferative activity in malignant melanoma cells regardless of their p53 status. Journal of dermatological science 62, 22-35.

Han, M.H., Yoo, Y.H., Choi, Y.H., 2008. Sanguinarine-induced apoptosis in human leukemia U937 cells via Bcl-2 downregulation and caspase-3 activation. Chemotherapy 54, 157 165.

Hersey, P., Bastholt, L., Chiarion-Sileni, V., Cinat, G., Dummer, R., Eggermont, A.M., Espinosa, E., Hauschild, A., Quirt, I., Robert, C., Schadendorf, D., 2009. Small molecules and targeted therapies in distant metastatic disease. Ann Oncol 20 Suppl 6, vi35-40.

Holy, J., Lamont, G., Perkins, E., 2006. Disruption of nucleocytoplasmic trafficking of cyclin D1 and topoisomerase II by sanguinarine. BMC Cell Biol 7, 13.

Hu, C.M., Cheng, Y.W., Liao, J.W., Cheng, H.W., Kang, J.J., 2005. Induction of contracture and extracellular $\mathrm{Ca} 2+$ influx in cardiac muscle by sanguinarine: a study on cardiotoxicity of sanguinarine. J Biomed Sci 12, 399-407.

Inan, S., Wei, H., 2010. The cytoprotective effects of dantrolene: a ryanodine receptor antagonist. Anesthesia and analgesia 111, 1400-1410.

Ishii, N., 2007. Role of oxidative stress from mitochondria on aging and cancer. Cornea 26, S3-9.

Islam, M.S., Rorsman, P., Berggren, P.O., 1992. $\mathrm{Ca}^{2+}$-induced $\mathrm{Ca}^{2+}$ release in insulinsecreting cells. FEBS Lett 296, 287-291.

Kemeny-Beke, A., Aradi, J., Damjanovich, J., Beck, Z., Facsko, A., Berta, A., Bodnar, A., 2006. Apoptotic response of uveal melanoma cells upon treatment with chelidonine, sanguinarine and chelerythrine. Cancer Lett 237, 67-75.

Kim, S., Lee, T.J., Leem, J., Choi, K.S., Park, J.W., Kwon, T.K., 2008. Sanguinarine-induced apoptosis: generation of ROS, down-regulation of Bcl-2, c-FLIP, and synergy with TRAIL. J Cell Biochem 104, 895-907.

Lee, J.S., Jung, W.K., Jeong, M.H., Yoon, T.R., Kim, H.K., 2012. Sanguinarine induces apoptosis of HT-29 human colon cancer cells via the regulation of Bax/Bcl-2 ratio and caspase-9-dependent pathway. International journal of toxicology 31, 70-77. 
Lenfeld, J., Kroutil, M., Marsalek, E., Slavik, J., Preininger, V., Simanek, V., 1981. Antiinflammatory activity of quaternary benzophenanthridine alkaloids from Chelidonium majus. Planta Med 43, 161-165.

Malikova, J., Zdarilova, A., Hlobilkova, A., 2006. Effects of sanguinarine and chelerythrine on the cell cycle and apoptosis. Biomed Pap Med Fac Univ Palacky Olomouc Czech Repub 150, 5-12.

Matkar, S.S., Wrischnik, L.A., Hellmann-Blumberg, U., 2008a. Production of hydrogen peroxide and redox cycling can explain how sanguinarine and chelerythrine induce rapid apoptosis. Arch Biochem Biophys 477, 43-52.

Matkar, S.S., Wrischnik, L.A., Hellmann-Blumberg, U., 2008b. Sanguinarine causes DNA damage and p53-independent cell death in human colon cancer cell lines. Chem Biol Interact $172,63-71$.

Menon, S.G., Coleman, M.C., Walsh, S.A., Spitz, D.R., Goswami, P.C., 2005. Differential susceptibility of nonmalignant human breast epithelial cells and breast cancer cells to thiol antioxidant-induced $\mathrm{G}_{1}$-delay. Antioxid Redox Signal 7, 711-718.

Mitscher, L.A., Park, Y.H., Clark, D., Clark, G.W., 3rd, Hammesfahr, P.D., Wu, W.N., Beal, J.L., 1978. Antimicrobial agents from higher plants. An investigation of Hunnemannia fumariaefolia pseudoalcoholates of sanguinarine and chelerythrine. Lloydia 41, 145150.

Mollinedo, F., Fernandez-Luna, J.L., Gajate, C., Martin-Martin, B., Benito, A., MartinezDalmau, R., Modolell, M., 1997. Selective induction of apoptosis in cancer cells by the ether lipid ET-18- $\mathrm{OCH}_{3}$ (Edelfosine): molecular structure requirements, cellular uptake, and protection by Bcl-2 and Bcl-X $\mathrm{X}_{\mathrm{L}}$. Cancer Res 57, 1320-1328.

Ng, F.W., Nguyen, M., Kwan, T., Branton, P.E., Nicholson, D.W., Cromlish, J.A., Shore, G.C., 1997. p28 Bap31, a Bcl-2/Bcl- $\mathrm{X}_{\mathrm{L}^{-}}$and procaspase-8-associated protein in the endoplasmic reticulum. J Cell Biol 139, 327-338.

Serafim, T.L., Matos, J.A., Sardao, V.A., Pereira, G.C., Branco, A.F., Pereira, S.L., Parke, D., Perkins, E.L., Moreno, A.J., Holy, J., Oliveira, P.J., 2008. Sanguinarine cytotoxicity on mouse melanoma K1735-M2 cells--nuclear vs. mitochondrial effects. Biochem Pharmacol 76, 1459-1475.

Tsukamoto, H., Kondo, S., Mukudai, Y., Nagumo, T., Yasuda, A., Kurihara, Y., Kamatani, T., Shintani, S., 2011. Evaluation of anticancer activities of benzo[c]phenanthridine alkaloid sanguinarine in oral squamous cell carcinoma cell line. Anticancer Res 31, 2841-2846. 
Vaquero, E.C., Edderkaoui, M., Pandol, S.J., Gukovsky, I., Gukovskaya, A.S., 2004. Reactive oxygen species produced by $\mathrm{NAD}(\mathrm{P}) \mathrm{H}$ oxidase inhibit apoptosis in pancreatic cancer cells. J Biol Chem 279, 34643-34654.

Verkhratsky, A., Shmigol, A., 1996. Calcium-induced calcium release in neurones. Cell Calcium 19, 1-14.

Weerasinghe, P., Hallock, S., Liepins, A., 2001. Bax, Bcl-2, and NF-kappaB expression in sanguinarine induced bimodal cell death. Exp Mol Pathol 71, 89-98.

Zhang, Y.H., Bhunia, A., Wan, K.F., Lee, M.C., Chan, S.L., Yu, V.C., Mok, Y.K., 2006. Chelerythrine and sanguinarine dock at distinct sites on $\mathrm{BclX}_{\mathrm{L}}$ that are not the classic BH3 binding cleft. J Mol Biol 364, 536-549.

Zhao, F., Li, P., Chen, S.R., Louis, C.F., Fruen, B.R., 2001. Dantrolene inhibition of ryanodine receptor $\mathrm{Ca}^{2+}$ release channels. Molecular mechanism and isoform selectivity. J Biol Chem 276, 13810-13816. 


\section{FIGURE LEGENDS}

Fig. 1. Decrease of cell viability by sanguinarine in human melanoma cells. (A) SK-MEL2 cells were treated with $1,2,3,4,5$ or $10 \mu \mathrm{M}$ sanguinarine (Sang) for 2 and $24 \mathrm{~h}$, and nonviable cells were counted using the Trypan Blue Dye Exclusion assay. Untreated control cells (C) were run in parallel. Data shown are mean $\pm \mathrm{SD}$ of three independent experiments. ${ }^{*} p<$ $0.05 v s$. untreated control $2 \mathrm{~h}$; \# $p<0.05 v s$. untreated control $24 \mathrm{~h}$, one-way ANOVA test, Bonferroni post-test. (B) Different melanoma cell lines were treated with $3 \mu \mathrm{M}$ sanguinarine (Sang) for $2 \mathrm{~h}$, and non-viable cells were counted using the Trypan Blue Dye Exclusion assay. Untreated control cells $(C)$ were run in parallel. Data shown are mean $\pm \mathrm{SD}$ of three independent experiments. ${ }^{*} p<0.05 v s$. untreated control, Student's $t$ test. (C) Time-course of the decrease in cell viability induced by $3 \mu \mathrm{M}$ sanguinarine in SK-MEL-2 cells. Data shown are mean $\pm \mathrm{SD}$ of three independent experiments. ${ }^{*} p<0.05$ vs. untreated control, one-way ANOVA test, Bonferroni post-test. (D) Representative images of sanguinarine-treated SKMEL-2 cells for the indicated times. These images were extracted from time-lapse videomicroscopy recordings, in which untreated control SK-MEL-2 cells or SK-MEL-2 cells treated with $3 \mu \mathrm{M}$ sanguinarine were recorded for $2 \mathrm{~h}$. The images were captured by using differential interference contrast (DIC). Bar, $50 \mu \mathrm{m}$.

Fig. 2. Caspase involvement in the cell-killing activity of sanguinarine on SK-MEL-2 cells. (A) Cells untreated $(C)$ or treated with $3 \mu \mathrm{M}$ sanguinarine for the indicated times were analyzed by Western blot using specific antibodies. The migration positions of full-length PARP $(116 \mathrm{kDa})$, and its cleavage product $\mathrm{p} 85$, as well as the cleavage products of several caspases are indicated. $\beta$-actin was used as a loading control in Western blot analyses. Blots are representative of two separate experiments performed. (B) SK-MEL-2 cells were preincubated with or without $50 \mu \mathrm{M}$ of $\mathrm{z}$-VAD-fmk for $1 \mathrm{~h}$, and then incubated in the presence or absence of $3 \mu \mathrm{M}$ sanguinarine (Sang) for 2 and $24 \mathrm{~h}$. Then dead cells were counted using Trypan Blue Dye Exclusion method. Untreated control cells were run in parallel. Data shown are mean $\pm \mathrm{SD}$ of three independent experiments. ${ }^{*} p<0.05 v s$. untreated control $2 \mathrm{~h}$; $\Phi p<0.05$ vs. Sang $2 \mathrm{~h}$; \# $p<0.05$ vs. untreated control $24 \mathrm{~h}$; $\theta p<0.05$ vs. Sang 24 h, one-way ANOVA test, Bonferroni post-test.

Fig. 3. Sanguinarine raises intracellular free calcium concentration in SK-MEL-2 cells. (A) Cells were incubated with $3 \mu \mathrm{M}$ sanguinarine (Sang) for $2 \mathrm{~h}$ and then Fluo-4 AM (green 
fluorescence) was used to visualize intracellular calcium. Hoechst 33342 stained nuclear DNA (blue fluorescence). Control image bar, $20 \mu \mathrm{m}$; sanguinarine image bar, $10 \mu \mathrm{m}$. (B) Cells were incubated with $3 \mu \mathrm{M}$ sanguinarine (Sang) for $2 \mathrm{~h}$, and then Fluo-4 AM (green fluorescence) was used to measure intracellular calcium by flow cytometry. Untreated control cells were run in parallel. Data shown are mean $\pm \mathrm{SD}$ of five independent experiments. ${ }^{*} p<$ 0.05 vs. untreated control, student's $t$ test. (C) SK-MEL-2 cells were untreated $(C)$ or treated with $3 \mu \mathrm{M}$ sanguinarine for the indicated times and analyzed by immunoblotting with antiBAP-31 antibody (SDS-15\% polyacrylamide gels). The migration position of its cleavage product p20 is indicated. Immunoblotting for $\beta$-actin was used as an internal control for equal protein loading in each lane. Blots are representative of two independent experiments performed. (D) SK-MEL-2 cells were preincubated with or without $10 \mu \mathrm{M}$ dantrolene for $1 \mathrm{~h}$, and then incubated in the presence or absence of $3 \mu \mathrm{M}$ sanguinarine (Sang) for $2 \mathrm{~h}$ and $24 \mathrm{~h}$. Then dead cells were counted using Trypan Blue Dye Exclusion method. Untreated control cells were run in parallel. Data shown are mean $\pm \mathrm{SD}$ of three independent experiments. ${ }^{*} p<$ 0.05 vs. untreated control 2 h; $\Phi p<0.05$ vs. Sang 2 h; \# $p<0.05$ vs. untreated control 24 h; $\theta$ $p<0.05$ vs. Sang 24 h, one-way ANOVA test, Bonferroni post-test.

\section{Fig. 4. Sanguinarine induces mitochondrial dysfunction and ROS generation in SK-}

MEL-2 cells. (A) Cells were incubated with $3 \mu \mathrm{M}$ sanguinarine (Sang) for $2 \mathrm{~h}$ and then DHE was used to detect ROS production. Untreated control cells were run in parallel. Data shown are mean $\pm \mathrm{SD}$ of four independent experiments. ${ }^{*} p<0.05 \mathrm{vs}$. untreated control, Student's $t$ test. (B) Cells were incubated in the absence (Control) and in the presence of $3 \mu \mathrm{M}$ sanguinarine (Sang), and then DHE (red fluorescence) was used to visualize oxygen radicals by confocal microscopy. DHE is oxidized into fluorescent ethidium by the superoxide ion. Hoechst 33342 stained nuclear DNA (blue fluorescence). Bar, 25 $\mu \mathrm{m}$. (C) SK-MEL-2 cells were treated with $1,2,3,4,5$ or $10 \mu \mathrm{M}$ sanguinarine (Sang) for 2 and $24 \mathrm{~h}$, and then $\mathrm{DiOC}_{6}(3)$ (green fluorescence) was used to measure the percentage of cells with high and low mitochondrial membrane potential $\left(\Delta \Psi_{\mathrm{m}}\right)$ by flow cytometry. Untreated control cells were run in parallel. Data shown are mean $\pm \mathrm{SD}$ of three independent experiments. ${ }^{*} p<0.05 v s$. untreated control $2 \mathrm{~h}$; \# $p<0.05 v s$. untreated control $24 \mathrm{~h}$, one-way ANOVA test, Bonferroni post-test. (D) Cells were incubated without or with $3 \mu \mathrm{M}$ of sanguinarine for $2 \mathrm{~h}$ and then TMRM (red fluorescence) was used to measure mitochondrial membrane potential $\left(\Delta \Psi_{\mathrm{m}}\right)$ by flow cytometry. Untreated control cells were run in parallel. Data shown are mean \pm SD of four independent experiments. $* p<0.05 v s$. untreated control, Student's $t$ test. (E) SK-MEL- 
2 cells treated with $3 \mu \mathrm{M}$ sanguinarine for the indicated times, and cytosolic proteins were analyzed by immunoblotting with anti-cytochrome $c(C y t c)$ and Smac/DIABLO antibodies. $\beta$-actin serves as an internal control for equal protein loading in each lane. Data shown are representative of two experiments performed.

Fig. 5. Bcl- $\mathrm{X}_{\mathrm{L}}$ overexpression does not prevent sanguinarine-induced decrease in cell viablity, ROS generation and release of mitochondrial apoptogenic proteins in SKMEL-2 cells. (A) Neo and $B c l-X_{L}$ transfected cells were untreated (C) or treated with $3 \mu \mathrm{M}$ sanguinarine (Sang) for $2 \mathrm{~h}$ and assayed for cell viability by the Trypan Blue Dye Exclusion assay. Data shown are mean $\pm \mathrm{SD}$ of five independent experiments. ${ }^{*} p<0.05$ vs. untreated control Neo; ${ }^{\#} p<0.05$ vs. untreated control $B c l-X_{L}$, one-way ANOVA test, Bonferroni posttest. Inset, Bcl- $\mathrm{X}_{\mathrm{L}}$ protein expression in SK-MEL-2-Neo and SK-MEL-2-Bcl- $X_{L}$ cells was analyzed by SDS-PAGE of $40 \mu \mathrm{g}$ cell extract protein and immunoblotting. $\beta$-actin was used as a control for protein loading. (B) Neo and $B c l-X_{L}$ transfected cells were untreated $(C)$ or treated with $3 \mu \mathrm{M}$ sanguinarine (Sang) for $2 \mathrm{~h}$ and assayed for PARP cleavage. The migration positions of full-length PARP $(116 \mathrm{kDa})$ and its cleavage product p85 are indicated. Immunoblotting for $\beta$-actin was used as an internal control for equal protein loading in each lane. Blots are representative of two separated experiments. (C) $\mathrm{Bcl}-\mathrm{X}_{\mathrm{L}}$ overexpression did not prevent sanguinarine-induced ROS production. SK-MEL-2 cells $(\mathrm{Neo})$ and Bcl- $\mathrm{X}_{\mathrm{L}^{-}}$ transfected SK-MEL-2 cells $\left(B c l-X_{L}\right)$ were treated with $3 \mu \mathrm{M}$ sanguinarine $($ Sang) for $2 \mathrm{~h}$, and then analyzed for ROS generation (using DHE). Untreated control cells (control) were run in parallel. Data shown are mean $\pm \mathrm{SD}$ of four independent experiments. ${ }^{*} p<0.05 v s$. untreated control Neo; ${ }^{\#} p<0.05$ vs. untreated control Bcl- $X_{L} ;{ }^{+} p<0.05$ vs. Sang Neo, one-way ANOVA test, Bonferroni post-test. (D) Bcl- $\mathrm{X}_{\mathrm{L}}$ overexpression did not prevent sanguinarineinduced release of apoptogenic proteins from mitochondria. Neo and $B c l-X_{L}$ transfected cells were untreated $(C)$ or treated with $3 \mu \mathrm{M}$ sanguinarine $(S a n g)$ for $2 \mathrm{~h}$ and cytosolic fractions were analyzed by immunoblotting with anti-cytochrome $c(C y t c)$ and Smac/DIABLO antibodies. $\beta$-actin serves as an internal control for equal protein loading in each lane. Data shown are representative of two separated experiments.

Fig. 6. Involvement of ROS generation in the antitumor action of sanguinarine in SKMEL-2 cells. (A) SK-MEL-2 cells were preincubated without or with $10 \mathrm{mM}$ NAC for 30 min, and then incubated in the presence or absence of $3 \mu \mathrm{M}$ sanguinarine (Sang) for $1 \mathrm{~h}$, and dead cells were determined using Trypan Blue. Untreated control cells $(C)$ were run in 
parallel. Data shown are mean $\pm \mathrm{SD}$ of three independent experiments. ${ }^{*} p<0.05 v s$. untreated control; ${ }^{*} p<0.05$ vs. Sang, one-way ANOVA test, Bonferroni post-test. (B) SK-MEL-2 cells were preincubated with or without $10 \mathrm{mM}$ NAC for $30 \mathrm{~min}$, and then incubated in the presence or absence of $3 \mu \mathrm{M}$ sanguinarine (Sang) for $2 \mathrm{~h}$ and analyzed by immunoblotting with anti-PARP antibody (SDS-8\% polyacrylamide gels). The migration positions of fulllength PARP (116 kDa) and its cleavage product p 85 are indicated. Immunoblotting for $\beta$ actin was used as an internal control for equal protein loading in each lane. Blots are representative of two experiments performed. (C) Cells were preincubated with or without 10 $\mathrm{mM}$ NAC for $30 \mathrm{~min}$, and then incubated in the presence or absence of $3 \mu \mathrm{M}$ sanguinarine (Sang) for $2 \mathrm{~h}$. Then ROS production was measured by flow cytometry. Data shown are mean $\pm \mathrm{SD}$ of four independent experiments. ${ }^{*} p<0.05$ vs. untreated control; ${ }^{\#} p<0.05$ vs. Sang, one-way ANOVA test, Bonferroni post-test. (D) Cells were preincubated with or without 10 $\mathrm{mM}$ NAC for $30 \mathrm{~min}$, and then incubated in the presence or absence of $3 \mu \mathrm{M}$ sanguinarine (Sang) for $2 \mathrm{~h}$. Cytosolic proteins were analyzed by immunoblotting anti-cytochrome $c$ (Cyt c) and Smac/DIABLO antibodies. $\beta$-actin serves as an internal control for equal protein loading in each lane. Untreated control cells $(C)$ were run in parallel in A-D. Data shown are representative of two experiments performed.

Fig. 7. Glutathione preincubation inhibits the sanguinarine-induced decrease in cell viability of SK-MEL-2 melanoma cells. SK-MEL-2 cells were preincubated with or without $10 \mathrm{mM}$ GSH for $1 \mathrm{~h}$, and then incubated in the presence or absence of $3 \mu \mathrm{M}$ sanguinarine (Sang) for 2 and $24 \mathrm{~h}$. Then non-viable cells were counted using Trypan Blue Dye Exclusion method. Untreated control cells were run in parallel. Data shown are mean $\pm \mathrm{SD}$ of three independent experiments. ${ }^{*} p<0.05$ vs. untreated control $2 \mathrm{~h} ; \Phi p<0.05$ vs. Sang $2 \mathrm{~h}$; \# $p<$ 0.05 vs. untreated control 24 h; $\theta p<0.05$ vs. Sang 24 h, one-way ANOVA test, Bonferroni post-test.

\section{SUPPLEMENTARY MATERIAL (VIDEOS)}

Supplementary Video 1. Time-lapse videomicroscopy of untreated control SK-MEL-2 cells, grown in complete RPMI-1640 culture medium supplemented with 15\% heat-inactivated FBS. Recording time: $3 \mathrm{~h}$. Magnification: 20x. 
Supplementary Video 2. Time-lapse videomicroscopy of the effect of sanguinarine on SKMEL-2 cells. Film recording started immediately after addition of $3 \mu \mathrm{M}$ sanguinarine on SKMEL-2 cells grown in complete RPMI-1640 culture medium supplemented with $15 \%$ heatinactivated FBS. Recording time: 3 h. Magnification: 20x. 
Figure 1.

Burgeiro et al.

A
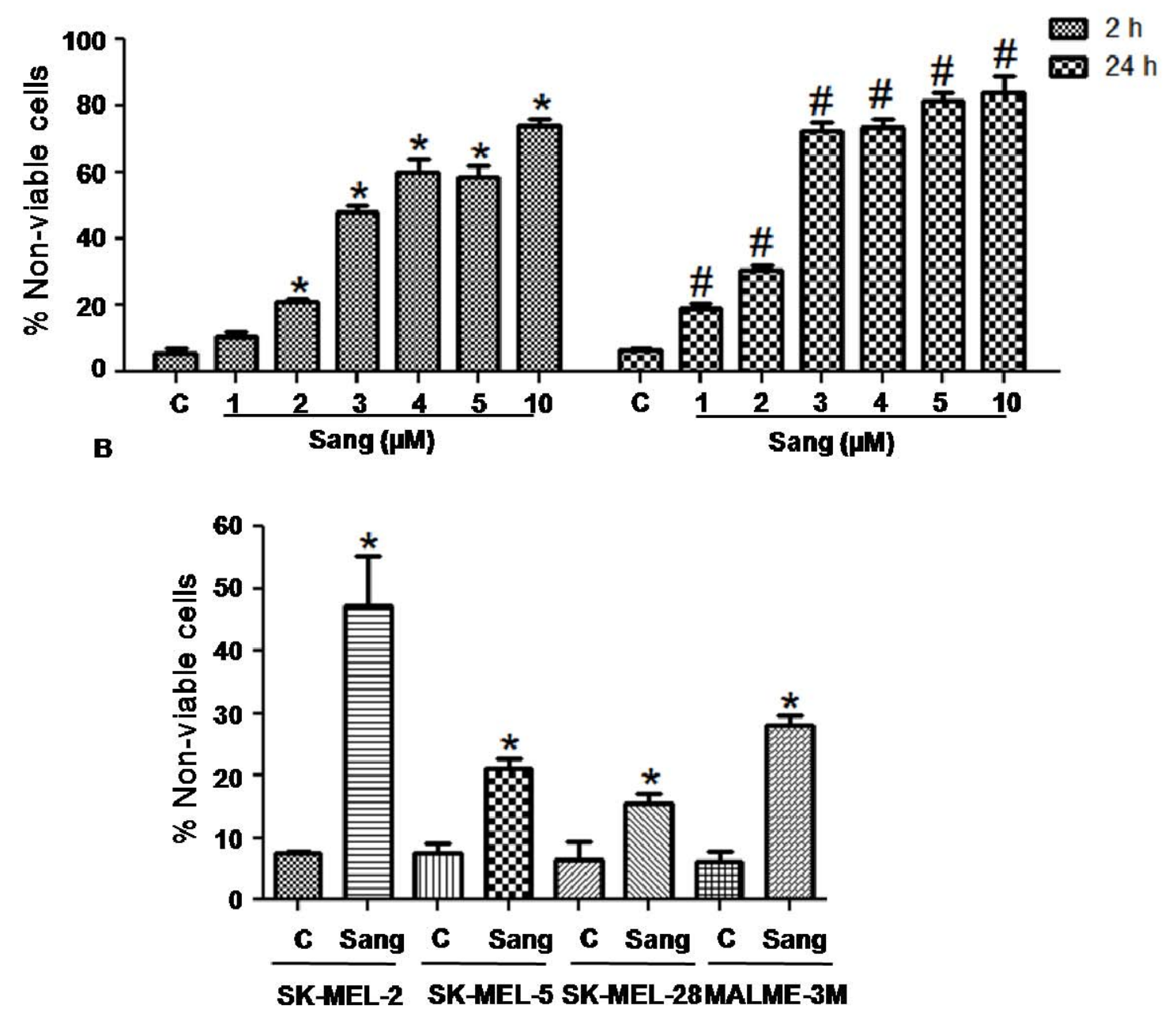

C

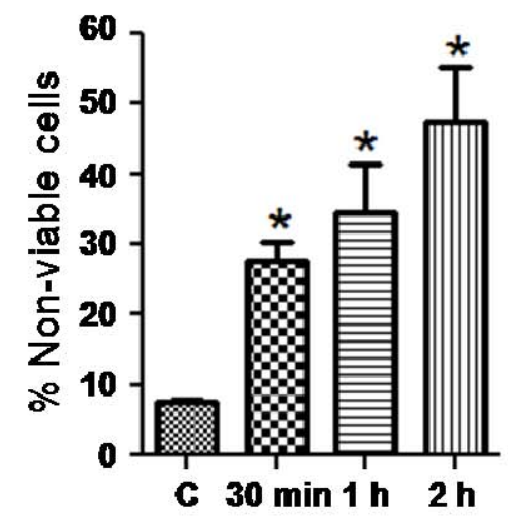

D

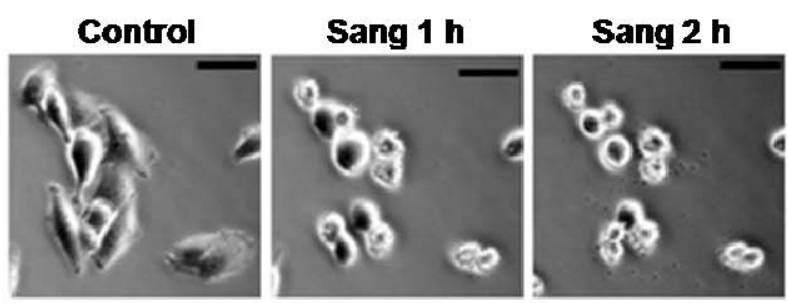


Figure 2.

Burgeiro et al.

A

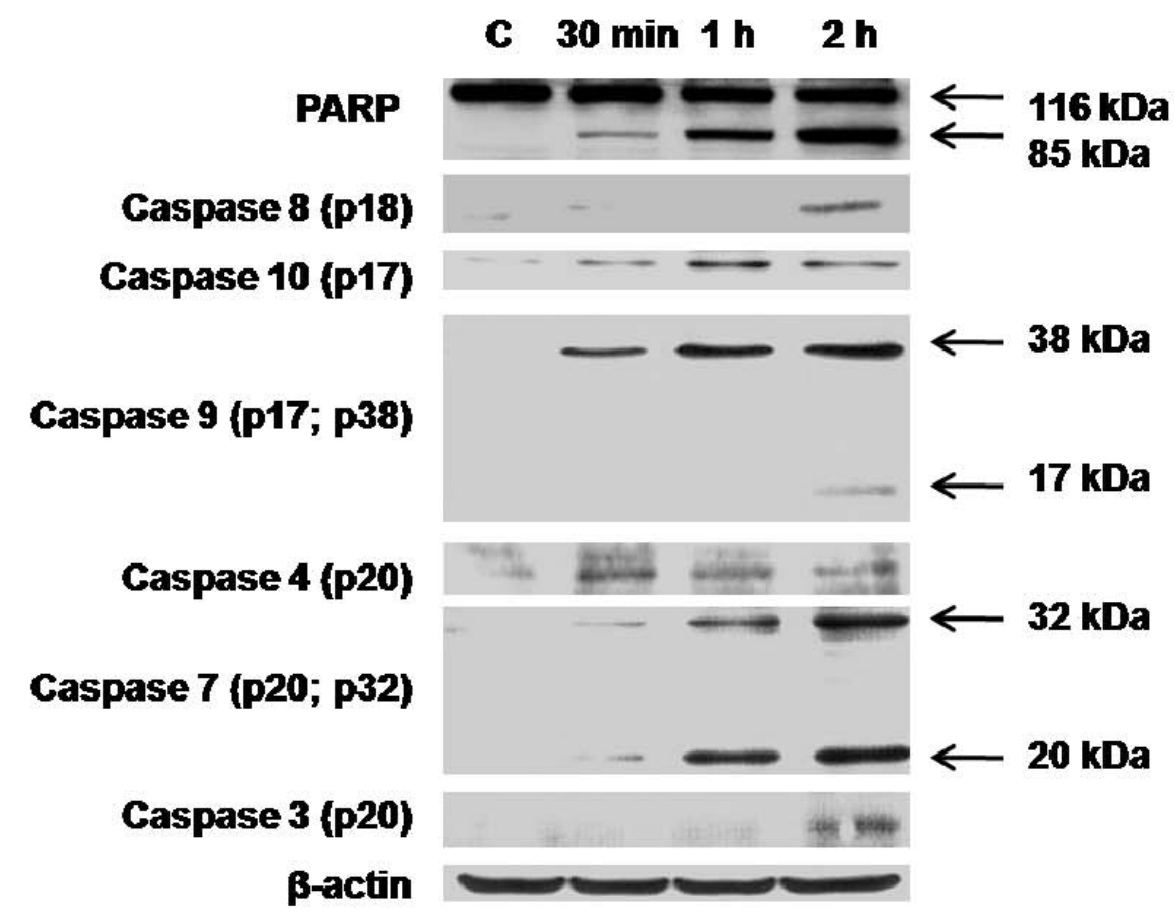

B

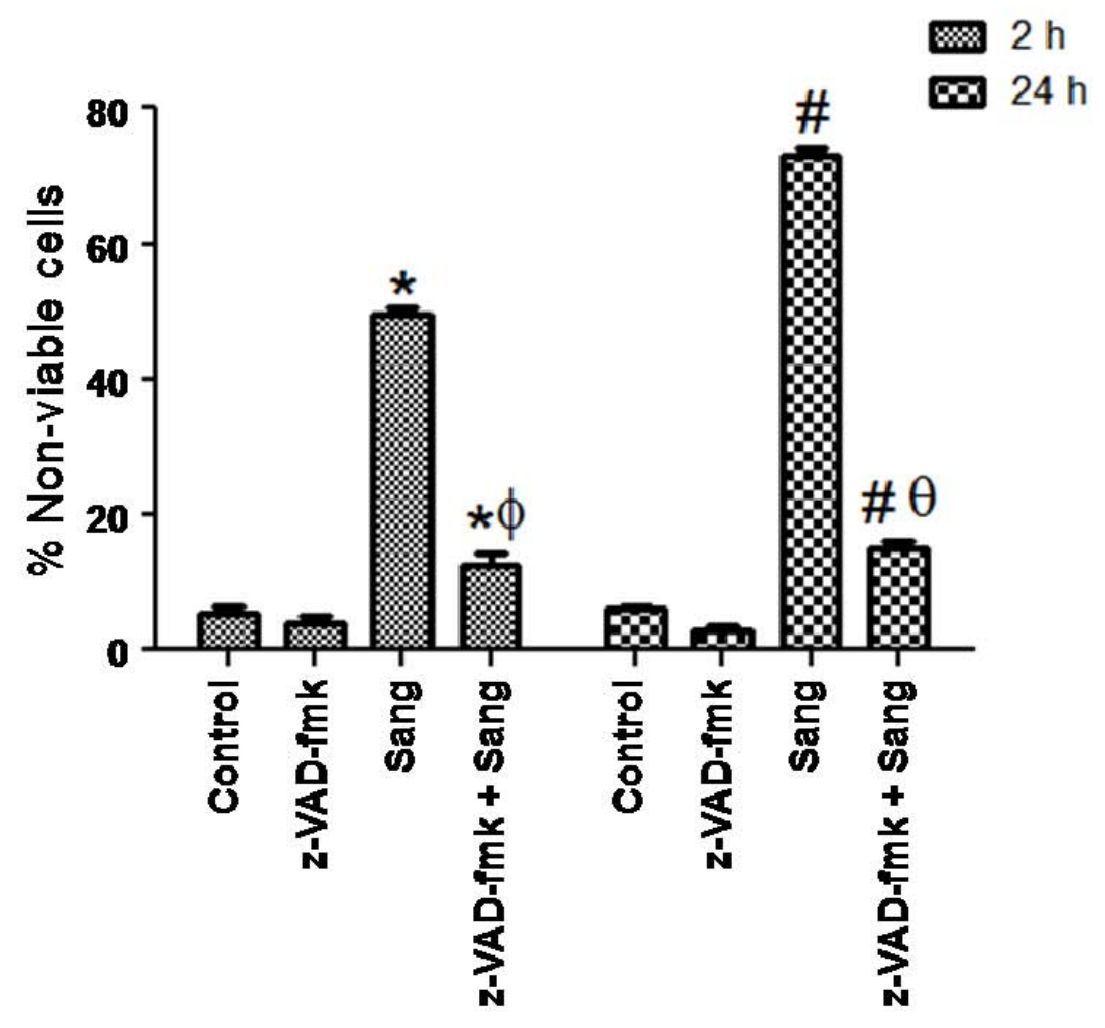


Figure 3.

Burgeiro et al.

A

B
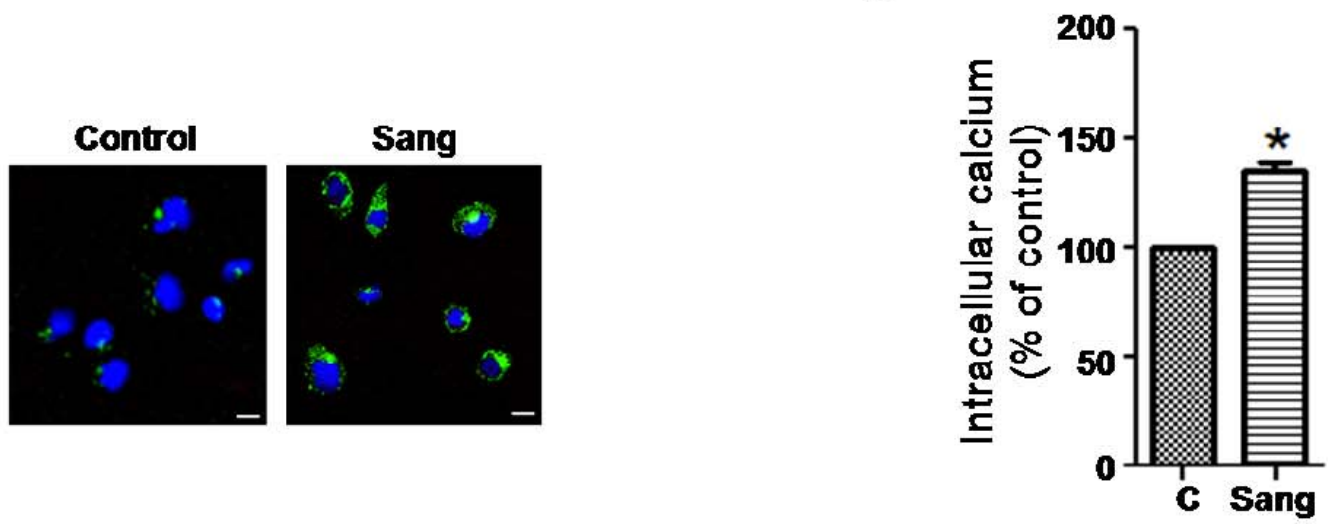

C

C 30 min $1 \mathrm{~h} \quad 2 \mathrm{~h}$

BAP-31 (p20)

B-actin

D

$2 \mathrm{~h}$

Ex $24 \mathrm{~h}$

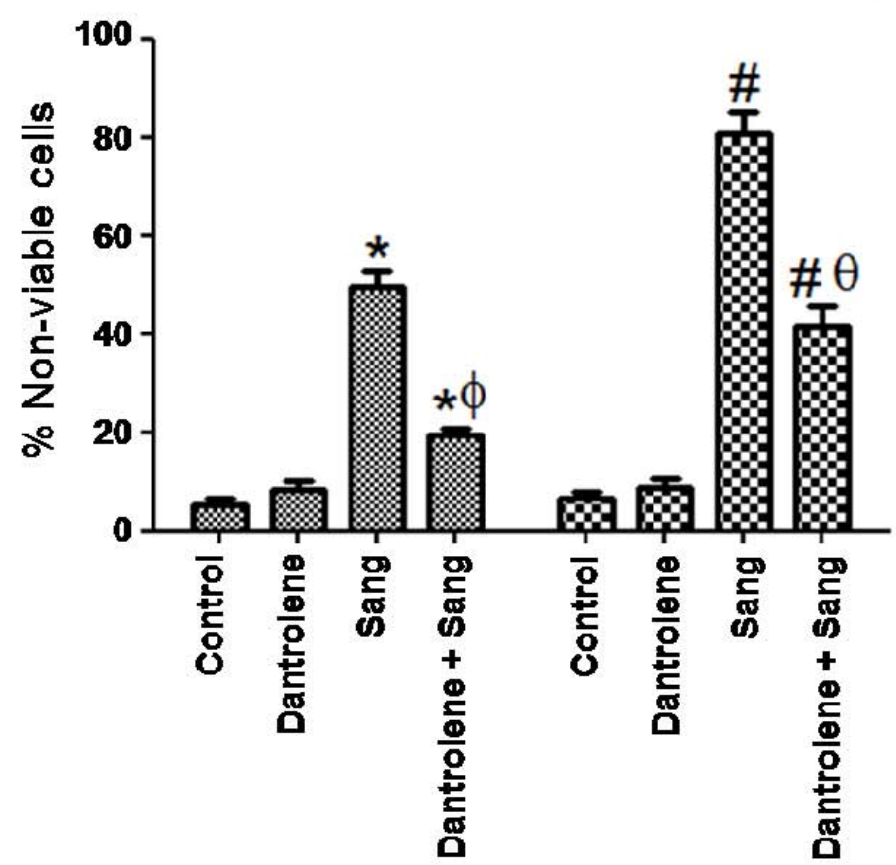


Figure 4.

Burgeiro et al.

A

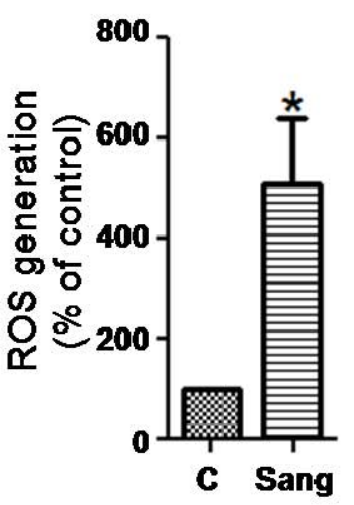

B

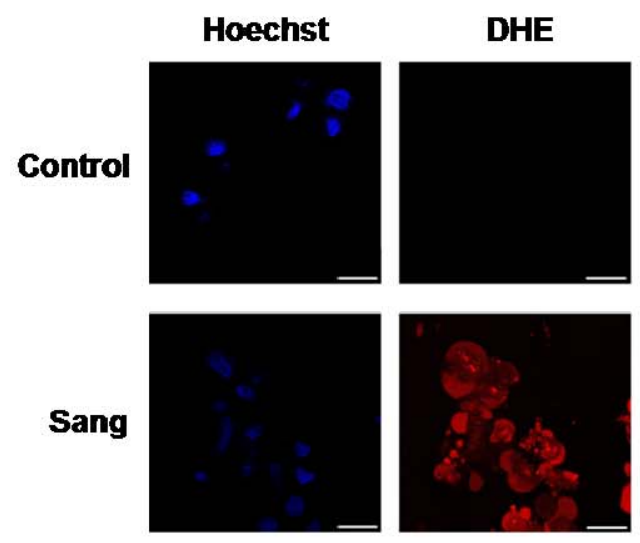

C

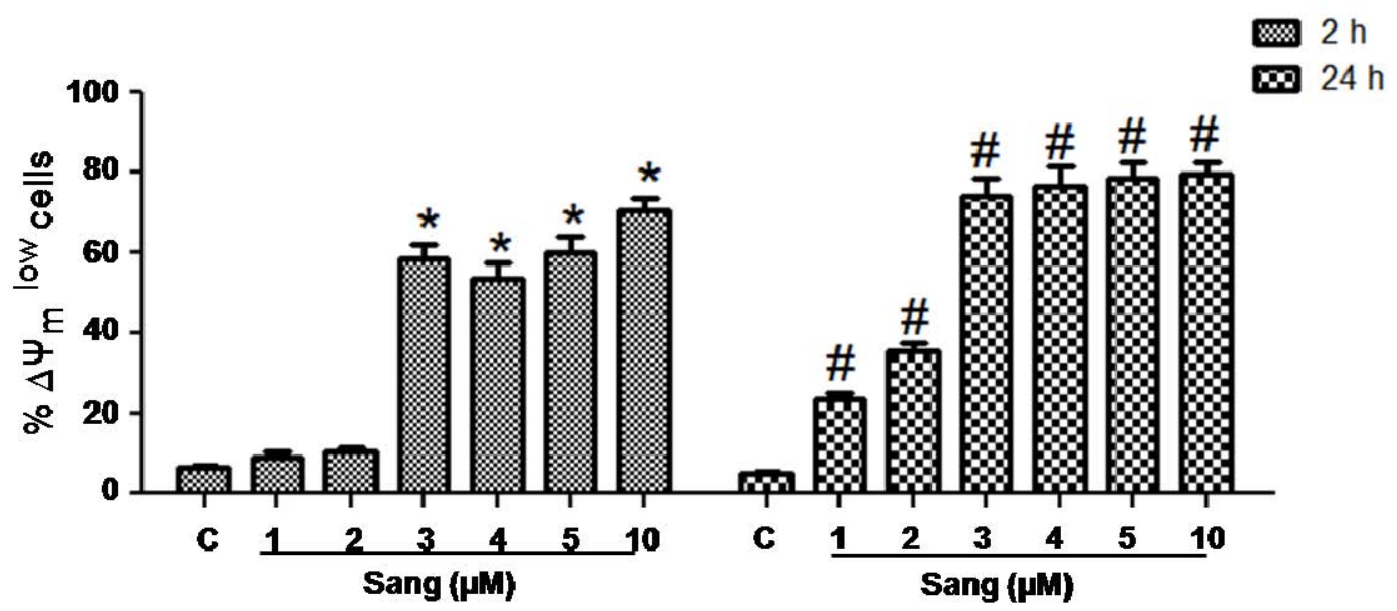

D

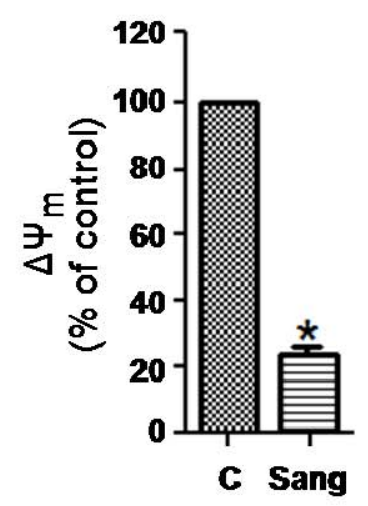

E

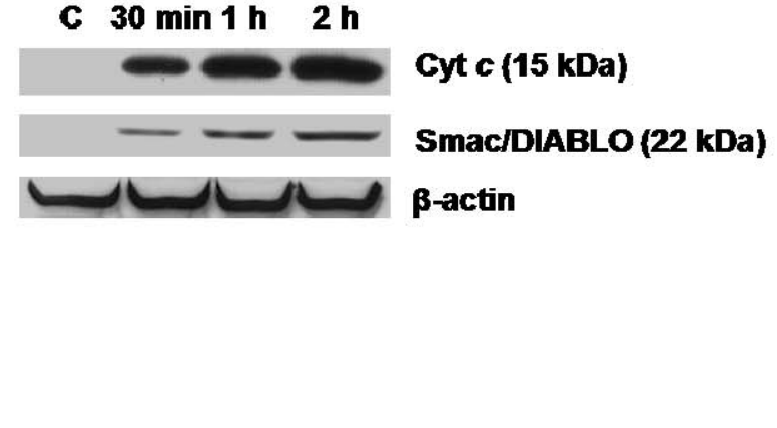


Figure 5.

Burgeiro et al.

A

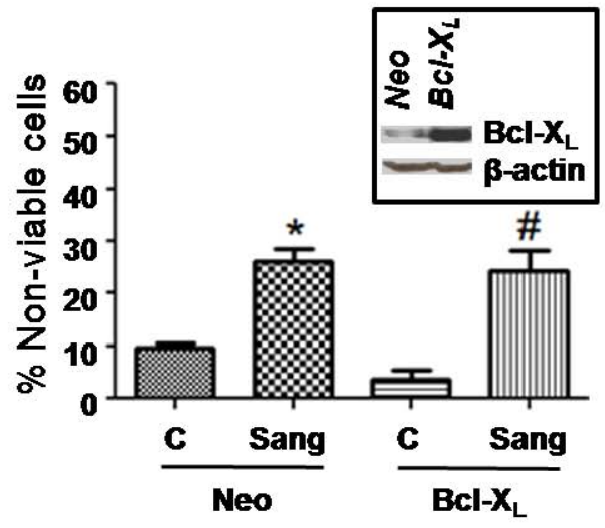

C

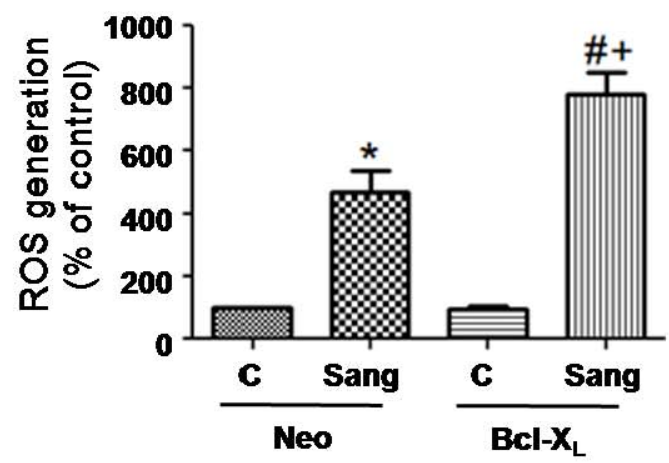

B

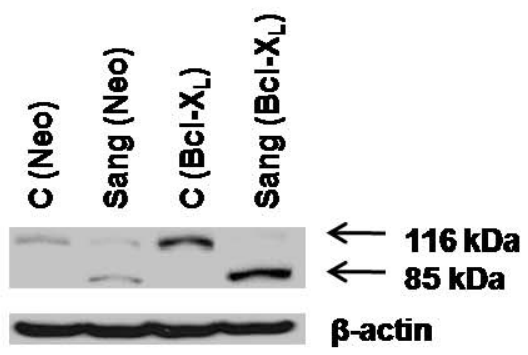

D

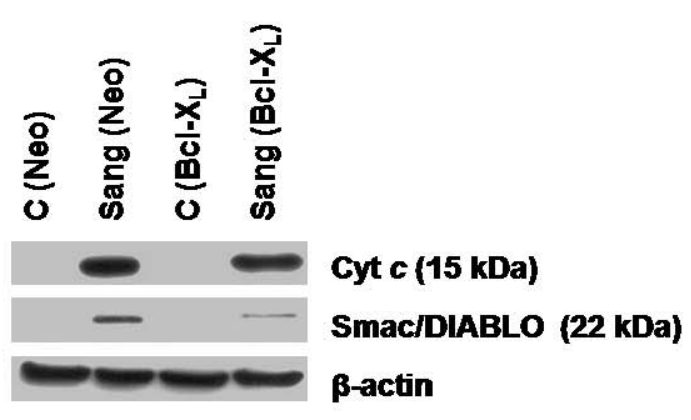


Figure 6.

Burgeiro et al.

A

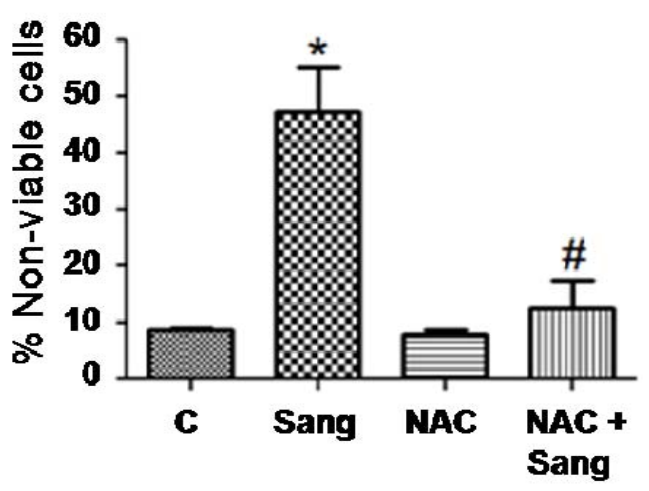

C

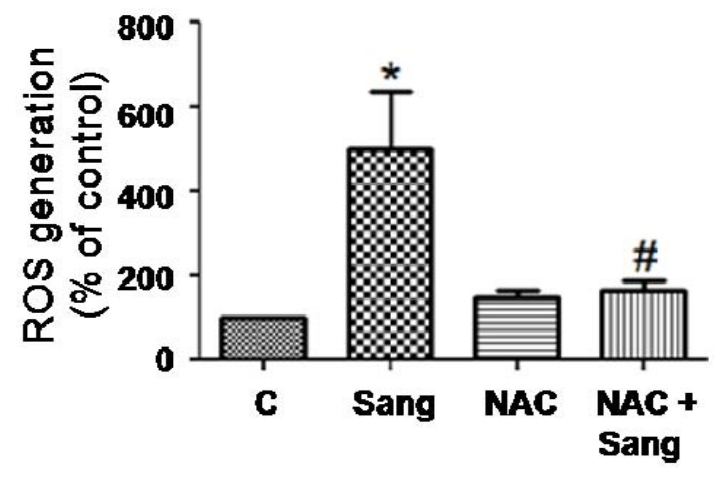

B

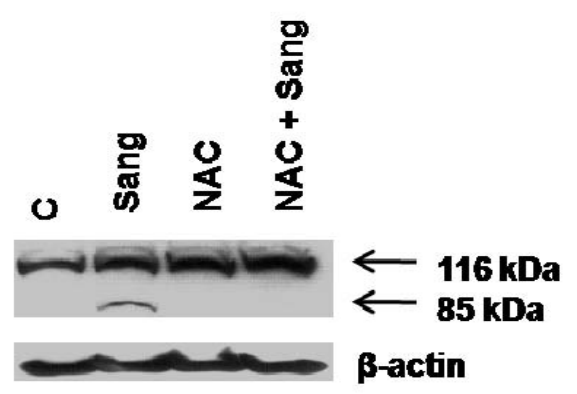

D

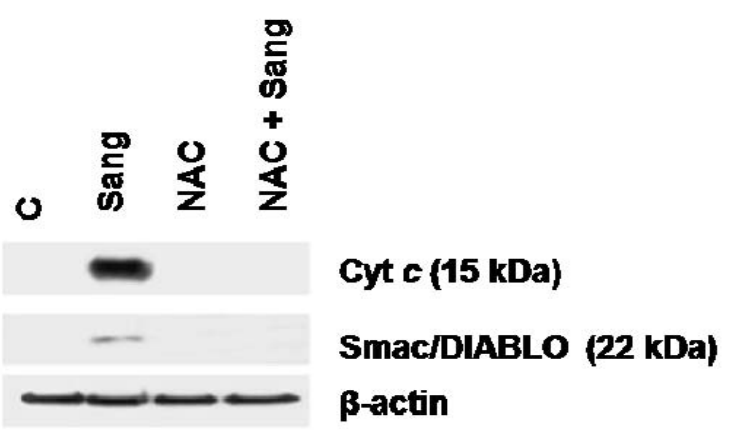


Figure 7.

Burgeiro et al.

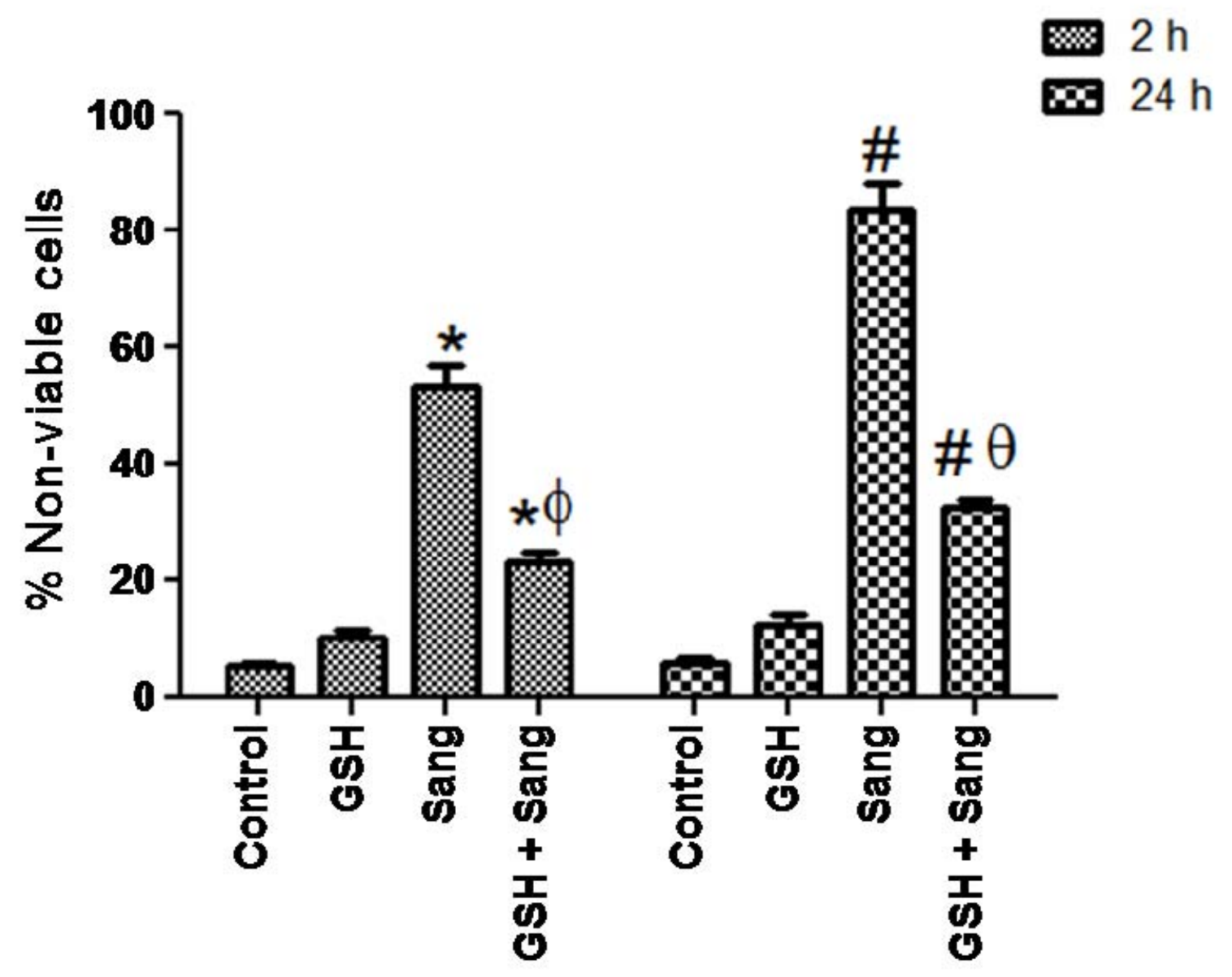

